\title{
GROUND NUT RESEARCH IN ODISHA, A CASE STUDY AND ANALYSIS
}

\author{
SUSHREE SIBANEE SARDAR ${ }^{1}$, KEDARESWAR PRADHAN $^{2} \&$ BIBHU SANTOSH BEHERA $^{3}$ \\ ${ }^{1,3}$ SRF-NRRI,Cuttack, Odisha, India \\ ${ }^{2}$ ADR-RRTTS,Semiliguda, Odisha, India
}

\section{ABSTRACT}

Thirty two F6 progenies with along with 4 released varieties as parents were evaluated in $R$. B. D for yield and its component traits grown during Rabi season showed a wide range of variation in all the 10 morphometric traits including yield. The genotypic source of variations was highly significant (at the 1\% level) for all the traits. The P. C. V. and G. C. V. Estimates were high for haulm yield per plant and low for harvest index and shelling percent. The rest of the characters exhibited medium PCV and GCV. However, low values of G. $C . V$. were observed in shelling percentage and harvest index indicated the need to create variability either by hybridization or mutation followed by selection. High heritability and high genetic advance indicated that these traits are mainly governed by additive gene action and respond to selection. Hence, improvement of these traits would be more effective through the phenotypic selection. Thus harvest index and shelling percent were controlled largely by non-additive gene action and selection would be less effective. Moderate heritability and genetic advance (GAM) as percent of mean for plant height, pod number per plant, kernel number per plant, kernel yield and pod yield indicated the additive and non additive gene actions for these traits and phenotypic selection would be effective to some extent. Kernel yield per plant had the highest direct positive effects on pod yield per plant followed by number of kernels per plant and 100 kernel weight. All other characters through these three characters made a major indirect contribution towards pod yield. Plant height, number of branches per plant and number of pods per plant exhibited greater influence on pod yield per plant via kernel number per plant and kernel yield per plant. Haulm yield and harvest index influenced indirectly on pod yield through kernel weight and kernel number respectively. Present studies thus indicated that for selection major emphasis should be laid on kernel yield per plant, number of kernels per plant, hundred kernel weight followed by plant height and number of branches per plant. Thus, kernel yield per plant, number of kernels per plant, hundred kernel weight followed by plant height and number of branches per plant were identified as the most important yield components and due emphasis should be placed on these characters while selecting for high yielding genotypes in Spanish bunch groundnut.

In the present study $D^{2}$ analysis was done. The advance breeding lines showed a considerable amount of diversity for the morphological traits. On the basis of average $D^{2}$, haulm yield per plant contributed maximum divergence followed by pod yield per plant, kernel yield and kernel number per plant. Shelling percent contributed least divergence. All other characters like plant height, number of branches per plant, harvest index, pod number per plant and hundred kernel weights contributed less to $D^{2}$ estimates.

On the basis of critical $D^{2}$ value (60), 36 genotypes were classified into 10 clusters. Four parents of Spanish groundnut released varieties and their 32 cross derivatives in F6 generation were grouped into ten 
different clusters. This indicated the large diversity existing in the groundnut varieties giving the opportunity for further improvement in groundnut. Thus, recently released varieties contain a sufficient diversity. Cluster $X, I X$ and III accommodated ten, eight and four genotypes respectively. The rest of the cluster contains two genotypes each. Cluster $X$ was the largest, accommodating as many as 10 genotypes. The progenies of AK 1224 X TG 26 were grouped into one cluster, i.e., cluster X, different from their parent present in cluster III. The progeny OG Y19 remained with its parent R2001-3 indicating its similarity with parent. Similarly OG Y5 and OG Y7 remained with one of their parent TG 26 while OG Z1 and OG Z2 clustered with one of their parent AK 159. Except these genotypes, other progenies remained in different clusters away from their parent. Thus hybridization among the released varieties in groundnut created genetic diversity due to recombination of characters. The clustering, pattern of genotypes showed that the genotypes of different origins/parent were clubbed into one cluster, whereas the genotypes belonging to same parent or origin were grouped into different clusters indicating that the new genetic recombination increased genetic diversity giving rise to transgressive segregants. Small intra cluster $D^{2}$ value of cluster I, II, IV, V, VI, VII and VIII indicated genotypes within a cluster resemble very close to each other. The genotypes of each cluster belong to same parental origin. Large intra cluster $D^{2}$ value of cluster III, IX and X indicated their less divergence. These three clusters also exhibited large inter cluster distance with the rest of the cluster. Maximum inter cluster distance was observed between cluster III and cluster X followed by cluster III and cluster IX. Inter cluster distance is the main criterion for selection of genotypes. In this context the genotypes from cluster III, IX and $X$ could be selected as parents for hybridization. Cluster IX showed the lowest number of branches per plant, harvest index, number of pods per plant, kernel number per plant and pod yield per plant while cluster $X$ exhibited highest value for haulm yield per plant and hundred kernel yield per plant. Thus OG Z5 may be selected as best parent for cross with AK 12-24 exhibiting high mean value for yield and yield contributing characters for obtaining better recombinants or may be advanced for use as a new improved breeding line.

But $O G$ Z 5 recorded highest pod and kernel yield per plant with haulm yield, although exhibited moderate chlorophyll and protein values. Chlorophyll, protein and yield were not related in the same magnitude and direction in all the crosses. The highest yield obtained in OG Z5 with moderate chlorophyll content is due to the balance in the physiological parameters contributing towards yield. Total chlorophyll is positively correlated with kenel yield and negatively with biological yield and vice versa.

The majority of the band ranges from 43.0 KDa to $14.3 \mathrm{KDa}$. Number of bands range from 11 to 19. 11 numbers of polymorphic bands are observed. Highest numbers of polymorphic bands are observed in AK 12-24, OG X1, OG X2, OG X3, OG Z2 and $O G \mathrm{Z3}$.

Comparing the composition of the clusters obtained using D2 values based on yield and yield contributing characters and dendrogram, based on protein banding pattern; it was observed that the divergent progeny $O G$ X4 in family AK 12-24 X TG 26 remained in cluster IX different from both the parent. Similarly the progenies like OG Y6, OG Y 7, OG Y 8, OG Y 18, OG Y20, OG Y 9, OG Y16, OG Y 10, OG Y 11, OG Y 13, OG Y 12 OG Y 15 and OG Y14 remained in different clusters other than the parent of cross $R$ 2001-3 X TG 26. In family AK 159 X TG 26, the progenies like $O G \mathrm{Z} 4$ and $O G \mathrm{Z1}$ remained in cluster IX with parent AK 159 but different from parent TG 26. Thus $O G \mathrm{Z1}$ and $O G \mathrm{Z4}$ exhibiting divergence at the protein level are 
expressed differently at the morphological level due interaction of morphological traits with the environment. Morphological traits expressed through the interaction of environments, put the genotypes of family $R$ 2001-3 $X$ TG 26 into different clusters, obtained based on protein banding.

OG Z5 \& OG Z6 may be identified as promising line for high protein content (25\%) and (31\%) with moderate chlorophyll and higher yield. OG X4 which is a high yielder and diversified line shown by protein banding may identify as a betting line.

Out of 36 genotypes evaluated the genotypes like OG Z5, OG Z2, R 2001-3A, OG Z6 and OG X4 were sorted out to be promising in respect of high yield. The higher productivity in these promising lines is due to a combination of various morpho- physiological traits and which could be ascribed as the basis of potential productivity in groundnut. High yield of different promising entries could be attributed to taller plant height,moderate to high number of branches /plant and number of pods per plant and moderately high 100 kernel weight, may serve as the basis of yield vigour which could be utilized as important selection criteria for prediction and realization of high yield in groundnut. KEYWORDS: Thirty Two F6 Progenies, Majority of Band Ranges \& Groundnut.

Received: Sep 18, 2017; Accepted: Oct 04, 2017; Published: Oct 12, 2017; Paper Id.: IJASRDEC20175

\section{INTRODUCTION}

Groundnut is an important oil, food, and a feed legume crop grown in over 100 countries. It covered 24 million ha area worldwide with a total production of 41 million tons in 2012 (FAOSTAT, 2012). Asia and Africa account for $95 \%$ of the global groundnut area where it is cultivated under rain-fed conditions with low inputs by resource poor farmers. In India, groundnut is cultivated in an area of $4.9 \mathrm{~m} \mathrm{ha}$, with production and productivity levels of $5.8 \mathrm{~m}$ tons and $1179 \mathrm{~kg} / \mathrm{ha}$ respectively during 2012. Groundnut is valued as a rich source of energy contributed by oil (48-50\%) and protein (25$28 \%$ ) in the kernels. They provide $564 \mathrm{kcal}$ of energy from $100 \mathrm{~g}$ of kernels (Jambunathan, 1991). In addition, the groundnut kernels contain many health enhancing nutrients such as minerals, antioxidants, and vitamins and are rich in mono-unsaturated fatty acids. They contain antioxidants like $p$-coumaric acid and Resveratrol, Vitamin E, and many important B-complex groups of thiamin, pantothenic acid, vitamin B-6, flats, and niacin. Over $60 \%$ of global groundnut production is crushed for extraction of oil for edible and industrial uses, while $40 \%$ is consumed for food purposes and the rest is used as seed for sowing the next season crop (Birthal et al., 2010). Groundnut oil is an excellent cooking medium because of its high smoking point (Singh and Diwakar, 1993).

The cultivated groundnut (Arachis hypogaea L.), an annual herb belonging to the family Fabaceae (Leguminosae), is classified into two subspecies, sub sp. fastigiata Waldron and subsp. hypogaea Krap. et al. The sub sp. fastigiata contains four botanical varieties, var. vulgaris, var. fastigiata, var. Peruvians, and var. aequatoriana. The subsp. hypogaea contains two varieties, var. hypogaea and var. Hirsute. Each of these botanical types has different plant, pod, and seed characteristics (Krapovickas and Gregory, 1994). Groundnut is an allotetraploid $(2 \mathrm{n}=2 \mathrm{x}=40)$ with AA and BB genomes. All species, except the cultivated species (A. hypogaea and A. monticola) in Section Arachis, and certain species in Section Rhizomatosae, are diploid $(2 \mathrm{n}=2 \mathrm{x}=20)$. The diploid progenitors, A. duranensis and A. ipaensis, contributed AA and BB genomes, respectively, to the cultivated groundnut (Kochert et al., 1996). The phylogenetic analyses based on 
intron sequences and microsatellite markers also provide evidence for this hypothesis (Moretzsohn et al., 2012). A single hybridization event, between the diploid progenitors followed by chromosome doubling (Kochert et al., 1996) about 3500 years ago, lead to origin of cultivated groundnut. Southern Bolivia and Northern Argentina are thought to be a center of origin of this crop (Gregory et al., 1980; Kochert et al., 1996). The center of diversity of the genus includes Western Brazil, Bolivia, Paraguay, and Northern Argentina (Gregory et al., 1980). A. duranensis occurs throughout the region, while A. ipaensis has only been found in Southern Bolivia. The genetic diversity of the genus is classified into four gene pools (Singh and Simpson, 1994). Primary gene pool consisting of A. hypogaea and A. The Monticola, secondary consisting of diploid species from Section Arachis that are cross compatible with A. hypogaea, tertiary consisting of species of the Section Procumbentes that are weakly cross-compatible with A. hypogaea, and the fourth gene pool consisting of the remaining wild Arachis species classified into seven other sections.

Yield and yield contributing parameters are the most widely targeted traits of groundnut improvement programs worldwide. Selection for yield per se has been the major basis for improving groundnut productivity (Nigam et al., 1991), however, the genetic gains from such selections have been low due to large $\mathrm{g} x \mathrm{e}$ interactions. The pod yield is a function of crop growth rate, duration of reproductive growth, and the fraction of crop growth rate partitioned toward pod yield. Therefore, understanding the physiological basis of yield and manipulation of physiological traits like crop growth rate, transpiration-use-efficiency, pre flowering photosynthetic translocation and post flowering photosynthetic contribution to yield, leaf area index, harvest index, etc. are as important as yield contributing parameters, i.e. Pod yield per plant, number of pods per plant, shelling outturn, and 100-seed weight for improvement of production and productivity in groundnut. Other traits like ease in shelling, ease in harvesting (peg strength), number of seeds per pod (for specific uses), reticulation, beak and constriction of the pod, kernel shape and color, and blanching ability are also important considerations to satisfy farmers, processors, and market demands. Haulm yield becomes an important consideration in addition to pod yield for the development of dual purpose varieties in groundnut. In addition to quantity of haulm produced, its quality is determined by nitrogen content and digestibility and which is also important to breed dual purpose varieties. Crop duration and fresh seed dormancy in Spanish varieties are important adaptation traits. The maturity duration should match with the length of growing period ranging from 90 to more than 150 days available at a given location and conditioned by the soil moisture availability and climatic conditions like temperatures and sunshine hours. Early maturity is an important trait in groundnut as it enables escape from stress conditions such as drought and frost and to fit in multiple cropping systems. In situ germination, a consequence of lack of fresh seed dormancy leads to significant loss in pod yield and affects the quality of produce in rainfed environments, particularly when rains coincide with the crop maturity.

Quality includes both, physical and chemical attributes. Nutritional traits include oil, protein, sugar, iron and zinc content, fatty acid profile, and freedom from toxins, while the other quality parameters include visual and sensory attributes like consumer and trader preferred traits and traits desirable in food/oil processing industries. Breeding for high yield and superior quality parameters enhances the economic returns to the farmers and other stakeholders along the value chain. Studies have shown that high oil content in groundnut translates into economic benefits to both farmer and millers. Similarly, the produce with desirable traits for confectionery uses fetches higher price in the market because of its export value. Traits impacting on food and oil uses are also important and which include both quality and nutritional parameters. Depending on the nature of use, low oil and high protein contents for food use, high oil content for oil use, and high oleic/linoleic fatty acid ratio for longer shelf-life are important targeted traits in advanced breeding programs. The traits for confectionery uses in India are, a greater proportion of sound mature kernels (SMK), flavor, 100 seed weight 
exceeding $55 \mathrm{~g},>11 \%$ of the sugar content, $>24 \%$ of the protein content, $>60 \%$ blanchability and low oil content $(<45 \%)$ (Ramanathan, 2004). Seed mass is an important attribute to confectionery quality; however, like yield and yield parameters, it is highly influenced by the environment. The taste and sensory attributes of roasted groundnuts are associated with carbohydrate components of the kernel (Pattee et al., 2000). Seed color and shape and flavor are the other important confectionery attributes. Blanchability is removal of taste or seed coat from raw or roasted groundnuts and this attribute is of economic importance in processed groundnut food products, which include peanut butter, salted groundnuts, candies, and bakery products and groundnut flour. Groundnuts are a rich source of several micronutrients, among which iron and zinc contents are important. Enhanced levels of iron and zinc by biofortification of different crop plants, including groundnut as a cost-effective and sustainable approach to fight malnutrition among the poor are gaining importance.

The genetic variability in groundnut is low due to the origin of the crop through a single hybridization event between two diploid species followed by a chromosome doubling and crossing barriers with wild diploid species due to ploidy differences. The cultivated groundnut is an allotetraploid, while all the wild Arachis species are diploids except A. monticola and certain species in Section Rhizomatosae. The low genetic variability for the traits of importance and polyploid nature are bottlenecks for the groundnut improvement. The cultivated accessions of Arachis hypogaea in the genebanks and the advanced breeding lines in the breeding programs are the most frequently used sources of variation in crop improvement programs. Groundnut genetic resources are available in the genebanks of ICRISAT, National Bureau of Plant Genetic Resources (NBPGR), and Directorate of Groundnut Research (DGR) in India; Oil Crops Research Institute of Chinese Academy of Agricultural Sciences and Crops Research Institute of Guangdong Academy of Agricultural Sciences in China; U. S. Department of Agriculture, Texas A\&M University, and North Carolina State University in the USA; EMBRAPA - CENARGEN and the Instituto Agronômico de Campinas in Brazil; and Instituto Nacional de Tecnología Agropecuaria (INTA) and Instituto de Botánica del Nordeste (IBONE) in Argentina.

Adequate amount of genetic variability and the genetic nature of the traits of interest are prerequisites for judicious selection of parents as well as the choice of appropriate breeding methods for the development of improved varieties in groundnut. However, much of the variability is still unexploited in groundnut improvement. It has been estimated that very few numbers of parental sources have been used in cross breeding programs as evidenced by the study of genealogy of the groundnut cultivars released in India. It has been reported that only three diseases resistant lines like $\mathbf{J}$ 11, NC Ac 17090 and PI 259747 has been exploited for the development of groundnut varieties combining high yield and disease resistance (Nigam, 2000). Therefore, the limited number of parents used for crop improvement programmes not only reduce the genetic diversity, but also the relative genetic uniformity of the released varieties, which becomes a threat for outbreaks of diseases and cause of yield plateauing in groundnut. Hence, it becomes imperative to ensure genetic diversity of the varieties currently cultivated by the farming community. As limited number of parental sources is available for crop improvement programmes, therefore, it becomes a serious and challenging problem for the breeders to make rapid improvement for development of varieties with high yield, better resistance and superior quality in groundnut.

Evaluation of new genetic material is one of the most important and expensive facets of most plant breeding programs. Large numbers of genotypes are advanced through segregating generations before superior cultivars are identified. If progeny performance in early generations accurately reflects the genetic potential of the cross, then identification and selection of superior crosses in early generations will allow the breeder to increase the number of selections per cross and increase the probability of identifying superior lines. This is especially important when resources 
are limited and/or a large number of lines must be evaluated. Selection for yield per se has been the basis for improving groundnut productivity in semi-arid environments (Nigram et al., 1991) but gain from such selection is slow due to large environmental effects. Further, inter-genotypic competition and a large experimental error associated with yield measurements often bias the outcome of selection for higher yield. Therefore, several workers in different crop plants have emphasized the importance of indirect selection for yield through component traits governed by genes with additive effect and with strong correlation with yield. Therefore, it would be rewarding and the efficiency of a single plant selection for yield would be improved via selection of other additional component traits rather than yield alone. Use of physiological models offer a means of identifying traits linked to yield and the selection of such traits for improvement of yield may enhance the efficiency of breeding (Williams, 1992). However, the exploitation of this approach in segregating populations has been seriously affected due to difficulties in measurement of physiological traits on per plant basis and which incur high cost.

Wallace et al. (1993) suggested that indirect selection for yield will be most effective when applied to traits that already integrate most of the genetic and environmental effects that lead to yield. Bandyopadhyay et al. (1985) evaluated the genetic potential of F2 progeny from single and three-way crosses using both physiological traits and components of yield. They found that F3 families derived from the top 25\% of F2 plants provided a higher frequency of selections for increased pod number than those derived from the top 50, 75 and 100\%. In addition, they found the frequency of superior selections to be higher in three-way crosses than single crosses, and a selection index based on physiological and yield components to be more effective than an index based on yield components alone. With appropriate selection intensities and the use of the selection index based on both physiological and yield components, effective selection for yield improvement in groundnut can be made as early as F2 generation. Iroume \& Knauft (1987) investigated early generation selection methods for the identification of peanut crosses with both high yield and resistance to leaf spot diseases. Their results suggested that in F2, selection among crosses would be advantageous over individual plant selection or within family selection. Selection of genotypes within crosses was the poorest strategy for selection in early generation. The effectiveness of early generation selection in peanut appears to be enhanced by limiting its use to traits of high heritability or to indirect selection for yield, based on selection for correlated traits. This is contrary to the results of Halward et al. (1990) who reported no relationship between yield of F3 and F4 and concluded that pod yields in early generations were ineffective in predicting the yield potential of crosses grown in bulk in later generations.

Realizing the importance of developing groundnut varieties with high yield, better resistance and superior quality and in the light of the above discussions, efforts were made to evaluate 32 breeding lines along with 4 parental lines during the course of present investigation for the assessment of

- Availability and extent of genetic variability in yield and yield attributing characters and other traits like chlorophyll and protein level.

- Nature and magnitude of character association in relation to yield and its components and various other traits.

- Direct and indirect effects of different component traits on yield through path analysis.

- Grouping of test genotypes into different units through $\mathrm{D}^{2}$ analysis, for their effective use as parents for genetic enhancement of yield.

- Identification of promising breeding lines and identification of different traits as important selection criteria for prediction 
of higher yield.

\section{MATERIALS AND METHODS}

The "Study on morphometric and molecular variation in groundnut breeding lines" was conducted under the Department of Plant breeding and Genetics college of Agriculture, OUAT, Bhubaneswar. The field trial was conducted in EB-II section of the Department of Plant breeding and genetics during Rabi season 2013-2014. The molecular work was conducted at the Department of Agricultural Biotechnology and Department of Plant Physiology, OUAT, Bhubaneswar.

\section{Materials for Field Plot Design for Evaluation}

Materials for the present experiment included 4 parental lines and 32 breeding lines (Table 1). The trial was shown on $21^{\text {st }}$ November, 2013 on Rabi season. Each entry was represented by three rows of $3 \mathrm{~m}$ length with 3 replications. the intercultural operations like hoeing, irrigation, weeding, fertilizer application were done in time. All the plant protection measures were followed. The crop was harvested on $29^{\text {th }}$ March 2014.

Table 1: Plant Materials, Their Source and Characters

\begin{tabular}{|c|c|c|c|}
\hline Variety No & Genotype & Source & Character \\
\hline 1 & AK 12-24 & Local variety & Well adopted var. \\
\hline 2 & TG-26 & Local variety & Better grain filling capasity \\
\hline 3 & $\mathrm{OG} \times 1$ & AK-12-24 × TG-26 & - \\
\hline 4 & $\mathrm{OG} \times 2$ & AK-12-24 × TG-26 & - \\
\hline 5 & $\mathrm{OG} \times 3$ & AK-12-24 × TG-26 & - \\
\hline 6 & $\mathrm{OG} \times 4$ & AK-12-24 × TG-26 & - \\
\hline 7 & $\mathrm{OG} \times 5$ & AK-12-24 × TG-26 & - \\
\hline 8 & R-2001-3 & Local variety & Higher number of pod/plant \\
\hline 9 & AK-159 & Local variety & Large seed and leaf size \\
\hline 10 & OGZ1 & AK-159 × TG-26 & - \\
\hline 11 & OGZ2 & AK-159 × TG-26 & - \\
\hline 12 & 0GZ3 & AK-149 × TG-26 & - \\
\hline 13 & 0GZ4 & AK-159 × TG-26 & - \\
\hline 14 & OGY1 & R-2001-3 × TG26 & - \\
\hline 15 & OGY2 & $\mathrm{R}-2001-3 \times \mathrm{TG}-26$ & - \\
\hline 16 & OGY3 & R-2001-3 × TG-26 & - \\
\hline 17 & OGY4 & R-2001-3× TG-26 & - \\
\hline 18 & OGY5 & $\mathrm{R}-2001-3 \times \mathrm{TG}-26$ & - \\
\hline 19 & OGY6 & R-2001-3 × TG-26 & - \\
\hline 20 & OGY7 & R-2001-3 × TG-26 & - \\
\hline 21 & OGY8 & $\mathrm{R}-2001-3 \times \mathrm{TG}-26$ & - \\
\hline 22 & OGY9 & $\mathrm{R}-2001-3 \times \mathrm{TG}-26$ & - \\
\hline 23 & OGY10 & R-2001-3 × TG-26 & - \\
\hline 24 & OGY11 & $\mathrm{R}-2001-3 \times \mathrm{TG}-26$ & - \\
\hline 25 & OGY12 & $\mathrm{R}-2001-3 \times \mathrm{TG}-26$ & - \\
\hline 26 & OGY13 & R-2001-3 × TG-26 & - \\
\hline 27 & OGY14 & R-2001-3 × TG-26 & - \\
\hline 28 & OGY15 & $\mathrm{R}-2001-3 \times \mathrm{TG}-26$ & - \\
\hline 29 & OGY16 & R-2001-3 × TG-26 & - \\
\hline 30 & OGY17 & R-2001-3 × TG-26 & - \\
\hline 31 & OGY18 & $\mathrm{R}-2001-3 \times \mathrm{TG}-26$ & - \\
\hline 32 & OGY19 & R-2001-3 × TG-26 & - \\
\hline 33 & OGY20 & R-2001-3 × TG-26 & - \\
\hline 34 & OGZ5 & AK-159 × TG26 & - \\
\hline 35 & OGZ6 & AK-159 × TG26 & - \\
\hline 36 & OGZ7 & AK-159 ×TG26 & - \\
\hline
\end{tabular}




\section{CHARACTERS STUDIED}

Ten yield and yield component characters such as plant height $(\mathrm{cm})$, number of branches. /plant, haulm weight $(\mathrm{g})$ /plant, harvest index, number of pods/plant, shelling percentage, number of kernels/plant, 100 kernel weight (g), kernel yield (g) /plant, pod yield (g) / plant were recorded. Observations were recorded for 5 plants by random sampling per genotype in each replication. The observations were recorded as follows.

- Plant height (cm): Average height of 5 random sample plants from the ground to the tip of main stem were recorded.

- Number of: Average number of branches emerging from a base of branches /plant the main shoot of 5 random sample plants was recorded.

- Haulm yield: The Average dry weight of 5 random sample plants /plant (g) was recorded.

- Harvest index: Recorded by taking the ratio of sound matures pod weight of 5 plants to biological yield of same 5 plants and expressed in \%. The biological yield was recorded as the sum total of dry weight of 5 plants and its pod yield.

- Pod number: Average pod no. of 5 random sample plants were /plant recorded

- Shelling \%: Weight of kernels obtained from $100 \mathrm{~g}$ of sound mature pods were recorded.

- Kernel number: The kernels from 5 plants were counted randomly at /plant, harvest to calculate mean kernels/plant

- 100 kernel wt: 100 sound mature kernels were taken from harvest bulk at random.

- Kernel yield/: Average weight of 5 random sample plants were plant recorded.

- Pod yield/: Average pod weight of 5 random sample plants was plant recorded.

\section{STATISTICAL ANALYSIS}

Observations on the 10 yield, yield component characters were recorded on 32 breeding lines and 4 parental lines in each of the three replications. Also mean observations were recorded for Chlorophyll and protein contents. Statistical analyses were carried out on the data recorded are outlined in the following paragraphs.

\section{Analysis of Variance}

Analysis of variance for each character was carried out in RBD with plot means for partitioning of total variance into components (Table 2). The test weight of significance of difference between lines was done by F test.

Table 2: ANOVA for RBD with Expectation of Mean Squares (MS)

\begin{tabular}{|l|c|l|l|c|}
\hline \multicolumn{1}{|c|}{ Source } & Df & MS & \multicolumn{1}{c|}{ F } & Expection of MS \\
\hline Replication(r) & $\mathrm{r}-1$ & $\mathrm{MSr}$ & $\mathrm{MSr} / \mathrm{MSe}$ & $\sigma_{\mathrm{e}}^{2}+\mathrm{g} \sigma_{\mathrm{e}}^{2}$ \\
\hline Genotype(g) & $\mathrm{g}-1$ & $\mathrm{MSg}$ & $\mathrm{MSg} / \mathrm{MSe}$ & $\sigma_{\mathrm{e}}^{2}+\mathrm{r \sigma}_{\mathrm{e}}^{2}$ \\
\hline Error(e) & $(\mathrm{r}-1)(\mathrm{g}-1)$ & $\mathrm{MSe}$ & - & $\sigma_{\mathrm{e}}^{2}$ \\
\hline
\end{tabular}

The test of the difference between means of two lines (genotypes) was done by $\mathrm{t}$ test and critical difference (CD at $5 \%$ ) was calculated as follows. 
$\mathrm{CD}($ at $5 \%)=(2 \mathrm{MSe} / \mathrm{r})^{1 / 2} \times \mathrm{t}_{0.5}$ at error $\mathrm{df}$

\section{Estimation of Genetic Parameters}

\section{Variance components}

The phenotypic, genotypic and environmental variance components for different characters were estimated from estimated from the mean squres in ANOVA according to Al-Jibouri et al.(1958) as follows

Environmental variance: $\left(\sigma_{\mathrm{e}}^{2}\right)=\mathrm{MSe}$

Genotypic variance: $\left(\sigma_{\mathrm{g})}^{2}=\frac{\mathrm{MSg}-\mathrm{MSe}}{\mathrm{r}}\right.$

Phenotypic variance: $\left(\sigma_{\mathrm{p}}^{2}\right)=\sigma_{\mathrm{g}}^{2}+\sigma_{\mathrm{e}}^{2}$

Where, MSg and MSe are mean squres due to genotype and error, respectively, and $r$ is the number of replications.

\section{Coefficient of variation}

The phenotypic and genotypic coefficient of variation for different characters was estimated as follows

Phenotypic coefficient of variation $(\mathrm{PCV})=\sigma_{\mathrm{p}} / \bar{x} \times 100$

Genotypic coefficient of variation $(\mathrm{GCV})=\sigma_{\mathrm{g}} / \bar{x} \times 100$

Where, $\sigma_{\mathrm{p}} \& \sigma_{\mathrm{g}}$ are the square root of phenotypic and genotypic variance, respectively and $\overline{\mathrm{x}}$ is grand mean for the characters.

\section{Heritability}

Estimation of heritability of different characters was done by the following formula using the components of variance as follows.

Heritability $\left(h^{2}\right)=\sigma_{g}^{2} / \sigma_{p}^{2}$

\section{Genetics Advance (GA)}

The expected genetic advance or genetic gain as a result selection intensity among the genotypes for different characters was calculated as follows:

$\mathrm{GA}=\mathrm{k} \cdot \mathrm{h} \cdot \sigma_{\mathrm{g}}^{2}=\mathrm{k} \cdot \mathrm{h}^{2} \cdot \sigma_{\mathrm{p}}$

Where, $\mathrm{k}=$ standardized selection differential for specified selection intensity

( $\mathrm{K}=2.06$ at $5 \%$ selection intensity)

$\mathrm{h}^{2}=$ heritability

$\mathrm{h}=$ heritability coefficient $=\sigma_{\mathrm{g}} / \sigma_{\mathrm{p}}$

$\sigma_{\mathrm{g}}=$ Square root of genotypic variance

$\sigma_{\mathrm{p}}=$ Square root of phenotypic variance 
For comparison of GA of different characters, GA was expressed as \% mean of the characters.

$$
\mathrm{GA}(\mathrm{As} \% \text { of men })=(\mathrm{GA} / \mathrm{mean}) \times 100
$$

\section{Estimation of Genotypic and Phenotypic Correlation}

The analysis of covariance between all possible pairs of 10 characters was done with plot mean as in Table 3 . The symbols and contents with respect to a component of covariance in mean sum of product are analogous to that of mean squares and the components of variance as described earlier.

Table 3: Analysis of Covariance in RBD with Expectation Mean Sum of Products (MSP)

\begin{tabular}{|l|c|l|c|}
\hline \multicolumn{1}{|c|}{ Source } & Df & MSP & Expectations of MSP \\
\hline Replication & $(\mathrm{r}-1)$ & $\mathrm{MSPr}$ & $\sigma_{\mathrm{e}(\mathrm{xy})}+\mathrm{g} \sigma_{\mathrm{r}(\mathrm{xy})}$ \\
\hline Genotype & $(\mathrm{g}-1)$ & $\mathrm{MSPg}$ & $\sigma_{\mathrm{e}(\mathrm{xy})}+\mathrm{r} \sigma_{\mathrm{g}(\mathrm{xy})}$ \\
\hline Error & $(\mathrm{r}-1)(\mathrm{g}-1)$ & $\mathrm{MSPe}$ & $\sigma_{\mathrm{e}(\mathrm{xy})}$ \\
\hline
\end{tabular}

The phenotypic, genotypic and error component of co-variance between two characters were estimated according to Al-Jibouri et al. (1958) in a similar manner as described under the components of variance.

The variance and co-variance analysis are made for the characters based on the 32 breeding lines with 4 parental lines as described earlier. Utilizing the various components of variance, co-variance, the genotypic, phenotypic correlation were computed according to Al-jibouri et al. (1958) by following a formula.

Genotypic correlation $\left(\mathrm{r}_{\mathrm{g}}\right)=\sigma_{\mathrm{g}(\mathrm{x}-\mathrm{y})} /\left[\sigma_{\mathrm{g}(\mathrm{x})}^{2} \cdot \sigma_{\mathrm{g}(\mathrm{y})]}^{2}\right.$

Where, $\sigma_{g(x y)}^{2}$ is the genotype co-variance between $\mathrm{x}$ and $\mathrm{y}$ and genotypic variance for the character $\mathrm{x}$ and $\mathrm{y}$ respectively.

Phenotypic correlation $\left(\mathrm{r}_{\mathrm{p}}\right)=\sigma_{\mathrm{p}(\mathrm{xy})} /\left[\sigma_{\mathrm{g}(\mathrm{x})}^{2} \cdot \sigma_{\mathrm{g}(\mathrm{y})}^{2}\right]$

Where, $\sigma_{p(x y)}^{2}$, is the phenotypic co-variance between $x$ and $y$ and $\sigma_{p(x)}^{2}$ and $\sigma_{p(y)}^{2}$ are phenotypic variance of $x$ and $\mathrm{y}$, respectively.

Significance of correlation co-efficient was tested by t-test with (n-2) degrees of freedom by the formula.

$$
\mathrm{t}=\frac{r}{[(1-r 2) /(n-2)] 1 / 2}
$$

Where, ' $r$ ' is the correlation co-efficient and ' $n$ ' is the number of genotypes.

\section{Path Coefficient Analysis}

The path co-efficient analysis gives cause and effect relationship among various co-related characters. Path coefficients are standardized partial regression co-efficient, which individually provide measures of the direct effect of each causal factor on the effect of variables. It permits partitioniong of correlations between the causal factors and effect variable into a component of direct and indirect effects, thus gives a better picture of association of causal factors with effect variable.

In present study pod yield is taken as 'effect' and 9 growth component characters related to yield as 'causal factors'. Path coefficients are obtained by solving simultaneous equations, which gives the basic relationship between correlations (Wright, 1921; Dewey and Lu, 1959) 


$$
\begin{aligned}
& \mathrm{p}_{1.10}+\mathrm{r}_{1.2} \mathrm{p}_{2.10}+\mathrm{r}_{1.3} \mathrm{p}_{3.10}+\ldots \ldots \ldots \ldots+\mathrm{r}_{1.11} \mathrm{p}_{11.10}=\mathrm{r}_{1.10} \\
& \mathrm{r}_{2.1} \mathrm{p}_{1.10}+\mathrm{r}_{2.3} \mathrm{p}_{3.10}+\mathrm{r}_{2.3} \mathrm{p}_{3.10} \ldots \ldots \ldots \ldots+\mathrm{r}_{2.11} \mathrm{p}_{11.10}=\mathrm{r}_{2.10}
\end{aligned}
$$

$\mathrm{r}_{9.1} \mathrm{p}_{1.10}+\mathrm{r}_{9.2} \mathrm{p}_{2.10}+\mathrm{r}_{9.3} \mathrm{p}_{3.10}+\ldots \ldots+\mathrm{p}_{9.10}=\mathrm{r}_{9.10}$

Where $r_{i j}$ is the correlation coefficient between $i^{\text {th }}$ and $j^{\text {th }}$ character and $p_{i, 10}$ is the path coefficient (direct effect) of $\mathrm{i}^{\text {th }}$ character on yield $\left(10^{\text {th }}\right.$ character $)$.

\section{Analysis of Genetic Diversity among Genotypes}

Genetic divergence analysis with regard to 10 quantitative traits among 36 groundnut genotypes was done by following method.

\section{$D^{2}$ ANALYSIS OF GENETIC DIVERGENCE}

Ten morpho-metric observations were recorded on five consecutive plants in each entry and replications and mean values of 36 entries were used for the analysis of genetic divergence using Mahalonobis's $\mathrm{D}^{2}$ statistic.

Mahalanobis 's D² statistic (Rao 1952) was used for estimation of genetic divergence among the 36 genotypes of groundnut 10 characters. Genetic divergence $\left(\mathrm{D}^{2}\right)$ between any two genotypes is given by the formula.

$$
D_{p}^{2}=W_{i j} d_{i} d_{j}
$$

Where, Wij is the inverse of the common dispersion matrix $\left(\mathrm{W}_{\mathrm{ij}}\right), \mathrm{d}_{\mathrm{i}}$ and $\mathrm{d}_{\mathrm{j}}$ are the difference in the means of the two genotypes for $\mathrm{i}^{\text {th }}$ and $\mathrm{j}^{\text {th }}$ characters.

The computation of $\mathrm{D}^{2}$ using this formula is complicated and laborious when a number of mutually correlated characters are involved in the divergence analysis. So the characters means were transformed into the set of uncorrelated variable using pivotal condensation of common dispersion matrix following (Rao, 1952). After this transformation, the formula for genetic divergence becomes

$$
\mathrm{D}^{2} \mathrm{p}=\mathrm{d}_{\mathrm{i}}^{2}
$$

Where $d_{i}$ is the difference between the transformed means of any two genotypes for the $i^{\text {th }}$ character. All possible $\mathrm{D}^{2}$ among the 36 genotypes were computed, the relative contribution of individual characters to divergence was assessed by (a) ranking of components $\mathrm{D}^{2}$ as well as by (b) $\%$ contribution to total $\mathrm{D}^{2}$ overall combinations.

- Rank average: In all the $\mathrm{D}^{2}$ combinations the characters were ranked 1-10 on the basis of their contribution to the $\mathrm{D}^{2}$. Then rank of each character is summed over all the $\mathrm{D}^{2}$ combinations to get rank total and then rank average is estimated.

- Average $\mathbf{D}^{2}$ : Average contribution to each character to all the $\mathrm{D}^{2}$ combinations is worked out.

\section{Grouping of Genotypes in to Different Clusters}

\section{Tocher's method}

Usually a cluster is defined as a group of genotypes or lines such that any 2 genotypes belonging to the same cluster, on an average, show a smaller $\mathrm{D}^{2}$ than those belonging to the different clusters. A simple device suggested by 
Tocher (Rao 1952) for construction of the cluster is to start with 2 most closely related genotypes (having the smallest $\mathrm{D}^{2}$ ) and then find a third one which has smaller average $\mathrm{D}^{2}$ from the first two and so on. At certain stage when it is felt that after adding a particular population, there is a disrupt increase in the average $\mathrm{D}^{2}$, this population is not added to the cluster. Similarly, construction of second and third and other clusters are formed till all the genotypes are included in one or the other cluster. Singh and Choudhari (1977) suggested a method for determining cut off value for the addition of a genotype / population to a cluster. In that the $\mathrm{D}^{2}$ values of each genotype with all others are to be arranged from the lowest to highest values in matrix form. The highest value of the lowest column is taken as cut off value for deciding on inclusion a genotype in the cluster. After construction of clusters average intra-cluster and tnter cluster D2 value were estimated.

\section{ESTIMATION OF CHLOROPHYLL CONTENT}

\section{Soil, Plant Analytical Development (SPAD) Chlorophyll Meter Reading (SCMR)}

Soil, plant analytical development (SPAD) chlorophyll meter reading (SCMR) was taken in 3 random sample leaf from the tip of the main stem at 60 days after sowing. Ambient light should be avoided during taking observation. Non destructive assessment of chlorophyll content has recently been widely done by chlorophyll meters based on measurement of leaf transmittance. The meter measures how much of the light of a certain wavelength (best absorbed by the chlorophyll molecules) is absorbed by the sample. The instrument measures the transmission of red light at $650 \mathrm{~nm}$, at which chlorophyll absorbs light, and transmission of infrared light at $940 \mathrm{~nm}$, at which no absorption occurs (Hoel, Solhaug 1998). Before the measurement, the instrument is calibrated - transmission is measured with no leaf inside. Thus, when a leaf is clamped by the meter, a certain portion of red light is absorbed and the meter can calculate a relative value (in SPAD, from Soil Plant Analysis Development, units), showing how green the leaf is. Basically, SPAD value correlates with the actual chlorophyll content in the leaf, but measurements have to be taken at many points of the same leaf to be representative and calibration is to be performed for every plant species or cultivar to know the exact relationship between SPAD values and chlorophyll contents per unit area. (i.e. after measuring chl. contents with the chlorophyll meter, pigments are to be extracted from the same leaf and its contents measured, for example, by spectrophotometry).

\section{REVIEW OF LITERATURE}

A review of literature on genetic variability for yield and yield related traits, correlation between yield and yield components, path analysis involving yield and other traits, genetic divergence, chlorophyll and protein content is presented below.

\section{Variability, Heritability and Genetic Advance}

Understanding the nature of the variability of the trait is important to select the breeding scheme to be employed for the improvement of the target trait. Both, qualitative and quantitative inheritance is reported for the traits of importance. The qualitative traits, as expected, are governed by a few genes [rust (Paramasivam et al., 1990), root-knot nematode (Choi et al., 1999), rosette virus (Nigam and Bock, 1990), branching pattern (Pattanashetti et al., 2008), and high O/L ratio (Moore and Knauft, 1989)]. Both quantitative and qualitative inheritance is also reported for several traits by different workers [(resistance to LLS; Motagi et al., 2000; Dwivedi et al., 2002), fresh seed dormancy (Khalfaoui, 1991; Upadhyaya and Nigam, 1999)]. Most often, there is preponderance of additive genetic variance for quantitative traits [drought tolerance traits (Upadhyaya, 2005), and seed size (Venuprasad et al., 2011)]. Presence of dominance variance and epistasis variance due to allotetraploid nature of the crop are also reported for most of the quantitative traits, but these 
cannot be exploited in a self-pollinated crop such as groundnut. Inheritance of some of the traits of economic importance is not yet fully understood. In many other cases, not much is known about their inheritance pattern because of lack of effective phenotyping tools.

In an 8 X 8 diallel of groundnut, Vishnuvardhan et al. (2013) obtained high GCV accompanied by high heritability and high GAM for number of secondary branches per plant, percentage of leaves affected by foliar diseases per plant and number of immature pods per plant indicating predominant role of additive gene action and amenability for phenotypic selection in early generations. Rust severity, number of mature pods per plant and pod yield per plant recorded high GCV and moderate heritability and GAM. Moderate GCV, moderate to low heritability and GAM were registered for number of primary branches per plant, kernel weight per plant, shelling out-turn, late leaf spot and harvest index indicating that additive and non-additive gene actions have a role in their inheritance and phenotypic selection would be effective to some extent. Days to 50 per cent flowering, days to maturity, plant height at harvest and sound mature kernel percentage recorded low GCV, high to moderate heritability and low GAM indicating larger role of non-additive gene action and selection would be effective in later segregating generations.

In a study of 142 F8 RILs of groundnut, Nandini et al.(2012) found phenotypic co-efficient of variation (PCV) to be higher than genotypic co-efficient of variation (GCV) with moderate to high degree of heritability and genetic advance for pod yield per plant, kernel yield per plant, pods per plant, sound mature kernel percentage, plant height, number of branches per plant and specific leaf area (SLA) indicating influence of environment and involvement of additive gene action in control of these traits. Low heritability and moderate genetic advance as per cent of mean was observed for SPAD Chlorophyll meter reading (SCMR).

\section{RESULTS AND DISCUSSIONS}

The present "Study on morphometric and molecular variation in groundnut breeding lines." was undertaken in the Department of Plant Breeding and Genetics, College of Agriculture, Orissa University of Agriculture and Technology, Bhubaneswar. The thirty six genotypes were evaluated comprised of 4 parents and their 32 progenies (Table 1). Field trial was conducted in RBD with three replications at EB-II during Rabi season of 2013-14.

Observations on ten quantitative characters like plant height $(\mathrm{cm})$, number of branches per plant, haulm yield per plant (g), harvest index (\%), number of pods per plant, shelling percentage, number of kernels per plant, 100 kernel weight (g), kernel yield per plant (g) and pod yield per plant (g) were recorded from the field trial. The data were analyzed to get information on genetic variation of yield and its components. Correlations among traits, direct and indirect effects of component traits on yield were estimated for selection of promising lines. Based on the genetic divergence the genotypes were grouped into different clusters. It would help in selection of parents for hybridization programme. Besides these, chlorophyll a, chlorophyll b, carotene and seed protein were estimated to study their relationship with yield. Attempt was made to study diversity among the genotypes based on electrophoresis banding of protein.

\section{Mean Performance of the Genotypes}

Mean performance of 36 genotypes for all the ten morpho-metric traits is presented in Table 6. The genotype TG 26 was the tallest plant with $22.73 \mathrm{~cm}$ in plant height. OG Z7 was observed to be shortest in plant height of $12.13 \mathrm{~cm}$. OG X1 exhibited lowest number of branches per plant (3.5), lowest harvest index (45.51), lowest number of pods per plant (9.43), lowest number of kernels per plant (13.67) and lowest kernel yield per plant (4.88 g). The highest number of 
branches per plant (8.07) was observed in OG Y14. OG Y7 exhibited the lowest haulm yield per plant (5.0 g) with highest harvest index (70.29). The haulm yield per plant was highest (15.67 g) in OG Z6. The parent R 2001-3 exhibited highest number of pods per plant (23.87) and kernels per plant (33.13). Among the genotypes, parent AK 12-24 exhibited lowest shelling percent and the other parent TG 26 exhibited highest shelling percent (79.84). The hundred kernel weight of test entries ranged from $33.27 \mathrm{~g}$ (OG Y1) to $67.65 \mathrm{~g}$ (OG Z5). Besides 100 kernel weight, OG Z5 exhibited highest value in both kernel yield (15.86 g) and pod yield (21.27g) per plant. The lowest kernel yield (4.88 g) and lowest pod yield (14.2 g) per plant was observed in OG X1 and OG X2 respectively. A perusal of the relative magnitude of variation from the analysis of variance and range of variations in respect of all the characters under study, revealed the presence of ample genetic variability in the material, thus providing eonomous scope for selection of genotypes andwhich could be used in the future breeding programmes for realization of high and stable yield in groundnut. Similar results The 4 parents and their 32 progenies showed wide variation in all the 10 traits including yield. The genotypic source of variations were highly significant (at $1 \%$ level) for all the traits table 5.

Table 5: Analysis of Variance of 10 Characters of Groundnut

\begin{tabular}{|c|c|l|c|c|c|}
\hline Sl. No. & \multicolumn{1}{|c|}{ Character } & Source & MSS & F & Prob>F \\
\hline \multirow{2}{*}{1} & \multirow{2}{*}{ Plant height $(\mathrm{cm})$} & Replication & 77.036 & $7.509 * *$ & 0.001 \\
\cline { 3 - 6 } & & Genotype & 22.722 & $2.215^{*}$ & 0.002 \\
\hline \multirow{2}{*}{2} & \multirow{2}{*}{ No of branches/ plant } & Replication & 7.763 & $14.999 * *$ & 0.000 \\
\cline { 3 - 6 } & & Genotype & 4.877 & $9.424 * *$ & 0.000 \\
\hline \multirow{2}{*}{3} & \multirow{2}{*}{ Haulm yield/ plant $(\mathrm{g})$} & Replication & 1.111 & 0.148 & 0.863 \\
\cline { 3 - 6 } & & Genotype & 23.375 & $3.110 * *$ & 0.000 \\
\hline \multirow{2}{*}{4} & \multirow{2}{*}{ Harvest index $(\%)$} & Replication & 27.975 & 0.968 & 0.385 \\
\cline { 3 - 6 } & & Genotype & 125.385 & $4.337 * *$ & 0.000 \\
\hline \multirow{2}{*}{5} & \multirow{2}{*}{ No. of pods/ plant } & Replication & 23.373 & 2.129 & 0.127 \\
\cline { 3 - 6 } & \multirow{2}{*}{6} & Genotype & 26.009 & $2.369 * *$ & 0.001 \\
\hline \multirow{2}{*}{7} & \multirow{2}{*}{ Nhelling $(\%)$} & Replication & 32.216 & 1.009 & 0.370 \\
\cline { 3 - 6 } & & Genotype & 89.110 & $2.791 * *$ & 0.000 \\
\hline \multirow{2}{*}{8} & \multirow{2}{*}{100 kernel weight $(\mathrm{g})$} & Replication & 1.082 & 0.072 & 0.931 \\
\cline { 3 - 6 } & & Genotype & 61.932 & $4.090 * *$ & 0.000 \\
\cline { 3 - 6 } & & Genotype & 160.773 & $8.022^{*} *$ & 0.000 \\
\hline \multirow{2}{*}{9} & \multirow{2}{*}{ Kernel yield/ plant $(\mathrm{g})$} & Replication & 0.230 & 0.053 & 0.949 \\
\cline { 3 - 6 } & & Genotype & 13.062 & $2.987 * *$ & 0.000 \\
\hline \multirow{2}{*}{10} & \multirow{2}{*}{ Pod yield/ plant $(\mathrm{g})$} & Replication & 2.037 & 0.265 & 0.768 \\
\cline { 3 - 6 } & & Genotype & 20.187 & $2.625 * *$ & 0.000 \\
\hline
\end{tabular}

* Significant at $5 \%$ level, **Significant at $1 \%$ level

\section{CONCLUSIONS}

By Making a Synthesizing Research on Ground Nut we may able to recommend our Farmers and researchers to accept good agriculture practices of the Ground Nut by following above technical methods.

\section{REFERENCES}

1. Bandyopadhyay, A., Arunachalan, V. and Venkajah, K. (1985). Efficient selection intensity in early generation index selection in groundnut (Arachis hypogaea L.). Theoretical and Applied Genetics, 71:300-304.

2. Dolma, T., Sekhar, M. R. and Reddy K. R. (2010). Genetic divergence studies in groundnut (Arachis hypogaea L.). J. Oilseeds Res, 27(2):158-160.

3. Faostat, 2012 
4. Halward, T. M., winne J. C. and Penso, E. J. M(1990). Effectiveness of early generation testing as applied to a recurrent selection programme in peanut. $\quad$ Peanut Science, 17:44-47.

5. Iroume, R. N. and D. A. Knauft (1987). Heritabilities and Correlations for Pod Yield and Leaf spot Resistance in Peanut (Arachis hypogaea L.). Implications $\quad$ for Early Generation Selection. Peanut Science: January, 14(1):46-50.

6. Jambunathan, R. (1991). Groundnut quality characteristics in Uses of $\quad$ tropical grain, 267-275.

7. Khote, A. C., Nichal, S. S; Patil, S.P. and Zape, A. S. (201O). Genetic divergence in some exoticgenotypes of groundnut ( Arachis hypogaea L.). J. Oilseeds Res. 27(2):161-163.

8. Moretzsohn, M. C., Gouvea, E. G., Inglis, P. W., Leal-Bertioli, S. C. M., Valls, J. F. M. andBertioli D. J. (2012). A study of the relationships of cultivated peanut(Arachis hypogaea and its most closely related wild species using intron sequences and microsatellite markers. Ann. Bot. 111:113-126.

9. Rao, C. R. (1952). Advanced statistical methods in biometric research.

10. Sonone, N. G., Thaware, B. L.; Bhave, S. G.; Jadhav,B. B.; Joshi, G. D. and Dhekale, J. S. (2011). Multivarate studies in groundnut. ( Arachis hypogaea L.). J. Oilseeds Res., 28(1):24-28.

11. Sudhir Kumar, Govindaraj, M. I. and Vijay,Kumar. (2010). Estimation of genetic diversity ofnew advanced breeding lines of groundnut (Arachis hypogaea L.). World j. Agric. Sci., 6(5):547-554.

12. Sudhir Kumar I; Marappa, N. and Govindaraj, M. (2010). Classification of new germplasm and advanced breeding lines of groundnut (Arachis hypogaea L.) through principal component analysis. Legume Res., 33(4) :242-248.

13. Suneetha, N., Vasanthi, R. P., Sudhakar, P. and Reddy, K. R. (2013)., Genetic diversity analysisamong released and prerelease cultures in groundnut. Legume Res., 36 (3) : 208 - 213, 2013.

14. Tang, Ronghua, et al. "Genetic diversity in cultivated groundnut based on SSR markers." Journal of Genetics and Genomics 34.5 (2007): 449-459.

15. Upadhyaya, H. D., Dwivedi, S. L., Nadaf, H. L. and Singh, S. (2011). Phenotypic Diversity and Identification of Wild. Euphytica, 182(1):103-115.

16. Vekataravana, P. and Marappa, N. (2010). Genetic divergence of new germplasm and advanced breeding lines of groundnut (Arachis hypogaea L.) studied under late kharif situation. Legume Res; 33 (2). 
